\title{
フィルム包装によるオウトウの鮮度保持効果
}

\author{
石川 豊*1§ $・$ 北澤裕明*1 $・$ 桑名陽子*2 ・高砂 健*3 \\ * 1 独農業・食品産業技術総合研究機構食品総合研究所 \\ * 2 茨城県農業総合センター園芸研究所 \\ * 3 山形県農業総合研究センター
}

\section{Modified Atmosphere Packaging for Maintaining Freshness of Sweet Cherry Fruit}

\author{
IshiKawa Yutaka*1\$, KITAZAwA Hiroaki*1, KuwanA Yoko*2 and TAKASAgO Ken*3 \\ * 1 National Food Research Institute, National Agriculture and Food Research Organization, \\ 2-1-12, Kannondai, Tsukuba, Ibaraki 305-8642 \\ * 2 Horticultural Institute, Ibaraki Agricultural Center, 3165-1 Ago, Kasama, Ibaraki 319-0292
}

* 3 Yamagata General Agricultural Research Center, 6060-27 Minorigaoka, Yamagata, Yamagata 990-2372

A method was proposed to determine the optimum packaging conditions for modified atmosphere packaging (MAP) of sweet cherry fruit. This fruit has an optimum gas composition for maintaining quality, however, we have yet to determine this optimum gas composition. Sweet cherry fruit respiration rates were measured in chambers in which different $\mathrm{O}_{2}$ concentrations were maintained. The gas permeability of plastic films were measured. Packaging conditions for producing different gas environments are a combination of package surface area and gas permeability, and under optimum conditions, the diffusion rates of oxygen and carbon dioxide into the package are equal to the respiration rate. Experimental $\mathrm{O}_{2}$ concentration results for sweet cherry fruit packaged in plastic films were in good agreement with the predicted in-package $\mathrm{O}_{2}$ concentrations. It was not necessary to experiment by trial and error to determine the optimum packaging conditions. Changes in in-package gas composition, sugar content, acidity, and appearance were determined for sweet cherry fruit storage at $20^{\circ} \mathrm{C}$. When $100 \mathrm{~g}$ of sweet cherry fruit was packaged in low-density polyethylene film (thickness : 18 and $36 \mu \mathrm{m}$, size $: 10 \times 10 \mathrm{~cm}$ ), $\mathrm{O}_{2}$ concentrations within the pouch were equilibrated at 1 $\sim 2 \%$ and $7 \sim 9 \%$ and these were found to be optimum for maintenance of axis wilting.

(Received Jan. 16, 2008 ; Accepted Jul. 24, 2008)

Key words : film, modified atmosphere packaging, quality, storage, sweet cherry フィルム, MA包装, 品質, 貯蔵, オウトウ

MA（Modified Atmosphere）包装は，野菜・果実の 品質保持手法の一つとして広く利用されている。一般に 袋内が低酸素, 高二酸化炭素䨌囲気になると青果物の呼 吸が抑制され，黄化や腐敗の進行，異臬生成の抑制，ク ロロフィルや糖, アスコルビン酸含量など内容成分の保 持に極めて効果的なことが知られている1”。これまでに， ニラ ${ }^{2)}$, 葉ネギ3), ナバナ ${ }^{4)}$ な゙多くの青果物についてそ の鮮度保持効果が報告されている。オウトウについても, MA包装やCA䝰蔵などガスコントロール環境下での品 質保持効果についての報告がある5 。しかし，オウトウ のMA包装について, 包装フィルムのガス透過度と包装
内ガス濃度変化, 品質保持効果を定量的に関連づけた報 告はほとんどない。

一方, 筆者らは, 貯蔵時間と袋内の酸素と二酸化炭素 濃度を関数にした呼吸モデルをつくり ${ }^{6)}$, 包装内ガス組 成変化をシミュレーションする手法 ${ }^{7 / 8)}$ や, 包装フィル ムのガス透過度とガスコントロール環境下での青果物の 呼吸量から包装内ガス組成を予測する方法 ${ }^{9}$ を用い, 最 適包装条件を予測する手法について報告した ${ }^{10)}$

本研究では, $20^{\circ} \mathrm{C}$ 条件下でのオウトウの呼吸量と包装 フィルムの酸素透過度から包装内酸素濃度を予測して, 包装条件を決定するとともに，各包装条件でのオウトウ

\footnotetext{
* 1 \% 305-8642 茨城県つくば市観音台 2-1-12

$\S$ 連絡先 (Corresponding author) E-mail : yishi@affrc.go.jp

* 2 于 319-0292 茨城県笠間市安居3165-1

* 3 テ990-2372 山形市みのりが丘6060-27
} 
の鮮度保持効果について明らかにしたので報告する。こ こでは，オウトウを低温貯蔵後に常温に戻した場合に果 実品質の低下が早く起こるとの報告 ${ }^{11}$ があることや，産 地においてあえて常温での流通がしばしば行われている ことなどから貯蔵温度を常温 $\left(20^{\circ} \mathrm{C}\right)$ として試験を行った。

\section{実験方法}

\section{1. 試 料}

供試試料は，2007年 6 月 22 日に山形県内で収穫した “佐藤錦”および2007年 7 月 1 日に同じく山形県内で収 穫した ‘紅秀峰”とした。収穫後ただちに段ボール詰め した試料を宅配便にて実験室まで常温配送し，翌日実験 室に到着後 $20^{\circ} \mathrm{C}$ に制御したチャンバー内に 24 時間保存し たものを試験に供した。

\section{2. オウトウの酸素消費速度測定}

直径 $9.96 \mathrm{~cm}$, 高さ $12.75 \mathrm{~cm}$ のアクリル製円筒容器内 にオウトウ ‘佐藤錦” 約 $350 \mathrm{~g}$ を入れた後, 所定の組成 に調整したガスをボンべより直接吹き込み（空気組成の ものはそのまま）密封した。アクリル製円筒容器胴部に はGC用セプタムを装着し, 密封した容器内のガスを 1

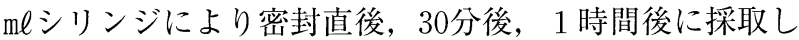
た。採取したガスはただちにガスクロマトグラフ（島津 GC-8A）により酸素，二酸化炭素，窒素濃度を測定した。 分析条件は，石川ら ${ }^{12)}$ の方法によった。なお，各ガスの TCD検出器に対する相対感度は，窒素100とすると酸素 94.3 ，二酸化炭素115.9であるため，各ピーク值を相対 感度で除した後, 平田らの方法 ${ }^{13)} に よ り$ 各ガス濃度值を 計算した。

測定した酸素濃度と容器内空容積 (容器体積 -オウト ウ体積）の積により容器内の酸素体積を求め, 容器内酸 素体積の時間変化をオウトウの酸素消費速度とした。

測定はすべて $20^{\circ} \mathrm{C}$ 条件下で行った。

\section{3. 包装資材および包装貯蔵試験}

包装資材は，低密度ポリエチレン（以下PEと略記） 厚さ $18 \mu \mathrm{m} ， 36 \mu \mathrm{m}$ の 2 種類を用いた。フィルムの酸素透過 度はそれぞれガス透過率測定装置（GTR-30X,GTRテッ ク社製）により $20^{\circ} \mathrm{C}$ で測定した。また，コントロール試 験区として有孔 $(\phi 6 \mathrm{~mm} \times 8$ 個 $) \mathrm{PE}$ (厚さ $18 \mu \mathrm{m})$ フィル ムを貯蔵試験に供した。貯蔵温度は $20^{\circ} \mathrm{C}$ ，貯蔵期間は, 果柄の萎调, 褐変が著しくなるまでとし, 佐藤錦は 7 日 間，紅秀峰は 9 日間とした。

\section{4. 目減り率}

約 $100 \mathrm{~g}$ のオウトウをフィルム包装し，貯蔵中の重量 変化を測定した。貯蔵前のオウトウ重量に対する貯蔵後 の重量\%を目減り率とした。

\section{5. 外 観 評 価}

オウトウの外観評価については，果柄の萎れ，果実の 光沢，水浸状の 3 項目について行った。果柄の萎れにつ いては， 3 名のパネリストにより果柄の萎れを0：変化 なし， 1 : 果柄の 5 割以下で萎调, 褐変, 2 : 果柄の 5
〜 割で萎调, 褐変, $3:$ 果柄の 7 割以上で萎调, 褐変, の 4 段階に分けて各区10個を調查し，その平均值を果柄 の萎れとして示した。果実の光沢評価は，0：変化な し, 1 : やや劣る, 2 : 光沢なし, 3 : 光沢なく, 果実 劣化著しいを評価基準とし, 水浸状態の発現の有無 は，0：なし，1：わずかに見られる，2：一部に見ら れる，3：果実全体に見られる，を評価基準とし，果柄 の萎れと同様 3 名のパネリストで各区 10 個を調査し，そ の平均值を示した。

\section{6. 糖酸度分析}

オウトウ 4 〜 個を乳鉢で磨砕し, 皮や種など固形分

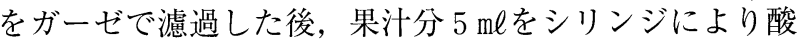
・糖度分析装置（堀場製作所製，NH-1000）に注入し, 糖酸度を計測した。

酸はクエン酸表示となっているため，リンゴ酸換算と した。

\section{結果}

\section{1．包装条件の設定}

アクリル製円筒容器内にオウトウ ‘佐藤錦” 約 $350 \mathrm{~g}$ を入れた後，酸素 $5 \%$ ，二酸化炭素 $10 \%$ ，窒素 $85 \%$ に調 整した混合ガスを吹き込んだ容器内の酸素濃度変化を Fig.1（a）に示し，それを容器内酸素体積に換算したもの をFig.1 (b) に示した。 4 回の測定による酸素体積変化は, それぞれ $7.58,6.84,8.81,7.89 \mathrm{~m} \ell / \mathrm{h}$ となり，平均值

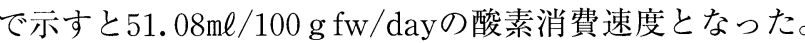

同様に酸素 $10 \%$ ，二酸化炭素 $5 \%$ ，窒素 $85 \%$ の混合ガ ス，酸素 $2 \% ，$ 二酸化炭素10\%，窒素 $88 \%$ の混合ガス，
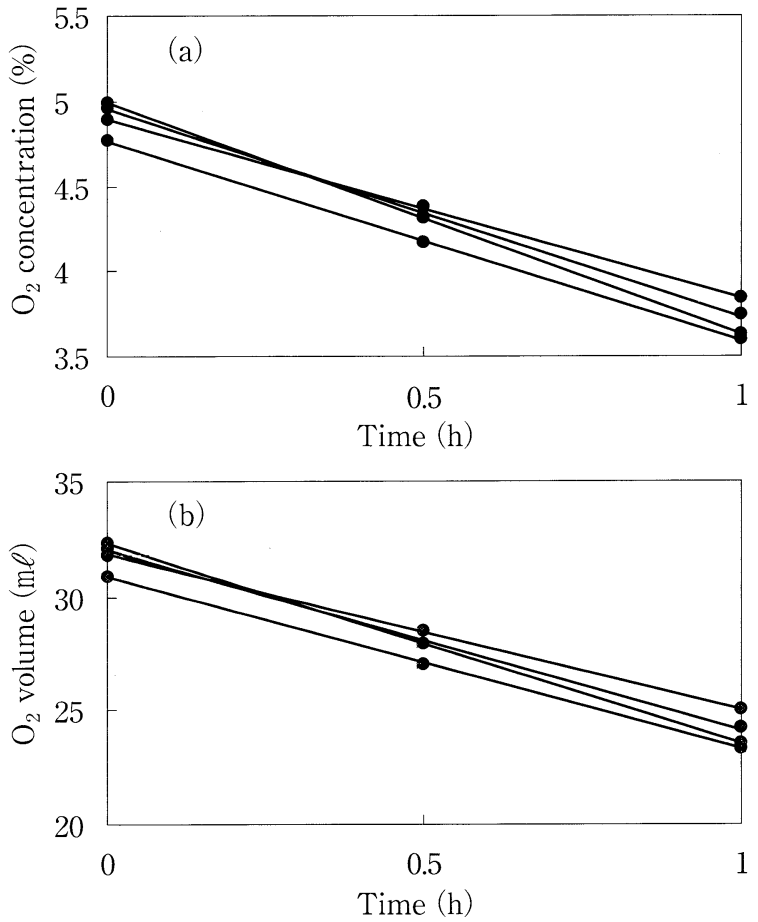

Fig. 1 Changes in $\mathrm{O}_{2}$ concentration and volume in containers of sweet cherry fruit 
空気をそれぞれ封入した場合の酸素消費速度を計測し， 酸素濃度の違いによる酸素消費速度変化を示した (Fig. 2)。

酸素濃度の低下にしたがって酸素消費速度の低下がみ られ，特に $5 \%$ 以下の低濃度条件において大きく低下す ることが明らかとなった。また，ここに示したガス環境 条件では，酸素消費速度と二酸化炭素排出速度の比であ る呼吸商はほぼ一定となり，この酸素濃度範囲では低酸 素条件においても嫌気呼吸とはなっていないことを確認 した。

MA包装による青果物の鮮度保持効果は，低酸素，高 二酸化炭素濃度条件下での呼吸の抑制によるものと報告 されている ${ }^{2) \sim 4}$ 。そこで本研究では, 大気条件下に対し て，酸素消費速度が $85 \% ， 70 \% ， 30 \%$ となるMA包装条 件を設定し，各包装条件での鮮度保持効果を調べた。

Fig. 2において大気条件下でのオウトウの酸素消費速 度は, 約 $77 \mathrm{~m} \ell / 100 \mathrm{~g}$ f.w./dayである。この消費速度の $85 \%$ は約 $66 \mathrm{~m} \ell / 100 \mathrm{~g}$ f.w./dayとなる。オウトウの酸素消費速 度を $66 \mathrm{~m} \ell / 100 \mathrm{~g}$ f.w./dayにまで低下させるためには，袋 内の酸素濃度を12〜13\%まで下げる必要がある。この酸 素濃度条件下でオウトウ $100 \mathrm{~g}$ の酸素消費速度とフィル ム面からの酸素透過速度が平衡になるようにフィルムの 種類，サイズを選択する。用意した低密度ポリエチレン フィルム (厚さ $18 \mu \mathrm{m})$ の酸素透過度は $20^{\circ} \mathrm{C}$ 条件下で 16,000 $\mathrm{m} \ell / \mathrm{m}^{2} \cdot \mathrm{day} \cdot \mathrm{atm}$ であった。このフィルムの酸素透過度 を酸素分圧差0.09atmで $66 \mathrm{~m} \ell /$ day とするためには表面積

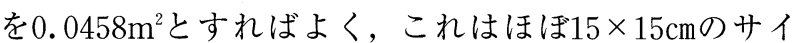
ズの袋に相当する。

同じように，オウトウの酸素消費速度を大気条件の約

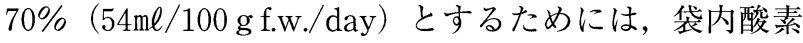
濃度を約 $6 \%$ まで下げる必要がある。ここでも同じ低密 度ポリエチレンフィルム（酸素透過度: $16,000 \mathrm{~m} \ell / \mathrm{m}^{2}$ ・ day・atm）を使った場合，酸素分圧差が $0.15 \mathrm{~atm}$ あ れば，表面積を $0.0225 \mathrm{~m}^{2}$ とすることでフィルム面から の酸素透過が $54 \mathrm{~m} \ell / \mathrm{day}$ となる。これはほぼ $10 \times 10 \mathrm{~cm} の$ サイズの袋に相当する。

オウトウの酸素消費速度を大気条件の約 $30 \%(23 \mathrm{~m} \ell /$ $100 \mathrm{~g}$ f.w./day) とするためには，袋内酸素濃度を約 $1.5 \%$ まで下げる必要がある。これは同じ低密度ポリエチレン

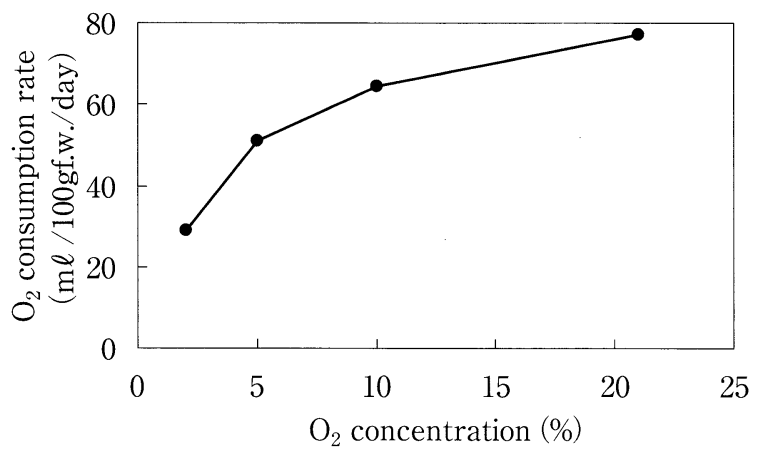

Fig. 2 Effect of $\mathrm{O}_{2}$ concentration on $\mathrm{O}_{2}$ consumption rate

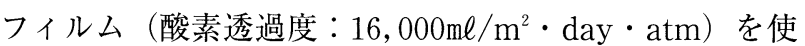
った場合，酸素分圧差が $0.195 \mathrm{~atm} ゙$ あれは，表面積が $0.0074 \mathrm{~m}^{2}$ とすることでフィルム面からの酸素透過が 23 $\mathrm{m} \ell /$ dayとなる。これはほほ $6 \times 6 \mathrm{~cm}$ のサイズの袋に相 当する。しかし，このサイズではオウトウ $100 \mathrm{~g}$ を包装 することができないため，ここでは酸素透過度：5,600 $\mathrm{m} \ell / \mathrm{m}^{2} \cdot$ day $\cdot \mathrm{atm}$ a $36 \mu \mathrm{mPE}$ Pィルムを使用した。表面 積が $0.0211 \mathrm{~m}^{2}$ であればフィルム面からの酸素透過が 23 $\mathrm{m} \ell / \mathrm{day}$ となる。これはほぼ $10 \times 10 \mathrm{~cm}$ サイズの袋に相 当する。

以上まとめると, Table 1 に示した 3 種類の包装条件 を設定した。この包装条件でオウトウ $100 \mathrm{~g}$ を包装し, 貯蔵試験を行った。

\section{2. 包装内ガス組成変化}

“佐藤錦” $100 \mathrm{~g}$ をTable 1 に示した包装条件におい て，20 $\mathrm{C} て ゙ 7$ 日間貯蔵した場合の包装内ガス濃度変化を Fig. 3（a）に示した。1 日目の包装内酸素濃度は，包装

Table 1 Properties of plastic films used for sweet cherry fruit packaging

\begin{tabular}{ccccc}
\hline & Film & $\begin{array}{c}\text { Thickness } \\
(\mu \mathrm{m})\end{array}$ & $\begin{array}{c}\mathrm{O}_{2} \text { transmission rate } \\
\left(\mathrm{m} \ell / \mathrm{m}^{2} \cdot \text { day } \cdot \mathrm{atm}\right)\end{array}$ & $\begin{array}{c}\text { Size } \\
(\mathrm{cm} \times \mathrm{cm})\end{array}$ \\
\hline (1) & $\mathrm{PE}(\mathrm{LDPE})$ & 18 & 16,000 & $15 \times 15$ \\
(2) & $\mathrm{PE}(\mathrm{LDPE})$ & 18 & 16,000 & $10 \times 10$ \\
(3) & $\mathrm{PE}(\mathrm{LDPE})$ & 36 & 5,600 & $10 \times 10$ \\
\hline
\end{tabular}

${ }^{*}$ Measured at $20^{\circ} \mathrm{C}$

PE (LDPE), Low-density polyethylene
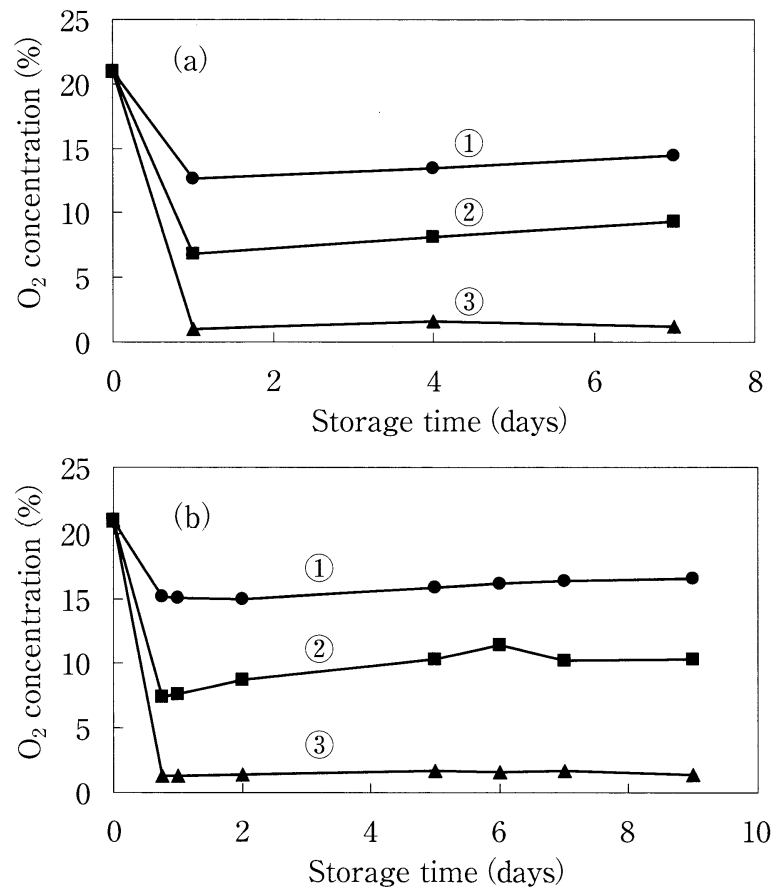

Fig. 3 Changes in $\mathrm{O}_{2}$ concentration in film packages of sweet cherry fruit

(a) 'Satohnishiki', (b) 'Benishuho'

(1), (2), (3), Reference to Table 1 
条件 (1): 12.6\%，(2): 6.8\%，(3):1.0\%となった。こ れは包装設計の際に予想した酸素濃度が (1)：12〜13\%， (2)：6\%，(3)：1.5\%であったことを考えるとほぼ設計 どおりの結果になったといえる。ただし，(2)，(3)では貯 蔵日数が経過するに従って酸素濃度が上昇する傾向がみ られた。これは貯蔵中にオウトウの品質変化が進み，呼 吸速度が低下した結果であると考えられる。

一方，“紅秀峰’ $100 \mathrm{~g}$ をTable 1 に示した包装条件に

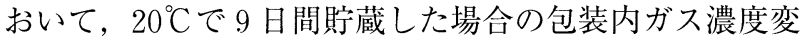
化をFig. 3（b）に示した。“佐藤錦” と比べていずれの 包装条件においても包装内酸素濃度が高い傾向がみられ た。これは ‘紅秀峰”の呼吸速度が “佐藤錦”に比べて 数\%程度低いためであったと考えられる。

また，図には示さなかったが，包装内二酸化炭素濃度 は，包装条件 (1)では約 2\%，(2)では約 4\%，(3)では約 10\%の濃度となった。

\section{3. 包装貯蔵中における目減り率}

Table 1 に示した 3 つの包装条件およびコントロール 試験区として有孔 $(\phi 6 \mathrm{~mm} \times 8$ 個 $) \mathrm{PE}$ (厚さ $18 \mu \mathrm{m})$ 包装 の計 4 条件で ‘紅秀峰’を $20^{\circ} \mathrm{C} ， 9$ 日間貯蔵した結果, コントロール試験区では明らかに大きな目減り率を示し た。一方，包装試験区では，(3)<(2)<(1)の順に目減り 率が増加したが，いずれも $1 \sim 2 \%$ 範囲であり, 大き な違いはみられなかった（Table 2)。

\section{4. 包装貯蔵中における外観評価}

Table 1 に示した 3 つの包装条件およびコントロール 試験区として有孔 $(\phi 6 \mathrm{~mm} \times 8$ 個 $) \mathrm{PE}($ 厚さ $18 \mu \mathrm{m})$ 包装 の計 4 条件で ‘紅秀峰”を $20^{\circ} \mathrm{C}, 9$ 日間貯蔵し, 果柄の 萎れ，光沢，水浸状の評価を行った（Table 3$)$ 。たた し, 貯蔵開始時に果柄の萎れ, 光沢，水浸状すべての評 価值が 0 である試料のみを試験に供した。

果柄の萎れに関する評価では，有孔PE包装区では 5 日後には果柄が完全に萎れてしまい（評価：3），商品 性が失われた。それに対して，包装内の酸素濃度が $15 \%$ 以上であった (1) 区では無包装区と同程度の萎れが生じ たが，(2)，(3)区では5 日目には1.6，7日目で2.0〜2.5 となり，包装条件により貯蔵性に大きな違いがみられる 結果となった。

一方, 光沢と水浸状の評価では, 包装条件により明確 な違いはみられなかった。

Table 2 Changes in weight loss in sweet cherry fruit packaged with plastic films

\begin{tabular}{ccccc}
\hline Storage time (day) & (1) & (2) & (3) & P-PE \\
\hline 1 & 99.8 & 99.9 & 99.9 & 98.2 \\
5 & 99.0 & 99.5 & 99.7 & 94.8 \\
7 & 98.6 & 99.3 & 99.6 & 92.2 \\
9 & 98.3 & 99.1 & 99.4 & 91.0 \\
\hline
\end{tabular}

P-PE, Perforated low-density polyethylene, non-packaged (1), (2), (3), Reference to Table 1
Table 3 Changes in wilting of axis, luster and hyperhydricity in sweet cherry fruit packaged with plastic films

Wilting of Axis

\begin{tabular}{ccccc}
\hline Storage time (days) & (1) & (2) & (3) & P-PE \\
\hline 1 & 0.73 & 1.00 & 0.80 & 0.80 \\
5 & 2.82 & 1.60 & 1.64 & 3.00 \\
7 & 2.80 & 2.50 & 2.00 & 3.00 \\
9 & 3.00 & 3.00 & 2.90 & 3.00 \\
\hline
\end{tabular}

\begin{tabular}{ccccc} 
Luster & \multicolumn{1}{l}{} \\
\hline Storage time (days) & (1) & $(2)$ & (3) & P-PE \\
\hline 1 & 0.09 & 0.27 & 0.10 & 0.20 \\
5 & 1.00 & 1.00 & 1.00 & 1.00 \\
7 & 1.27 & 1.00 & 1.18 & 1.27 \\
9 & 1.64 & 1.60 & 2.00 & 1.64 \\
\hline
\end{tabular}

Hyperhydricity

\begin{tabular}{ccccc}
\hline Storage time (days) & (1) & (2) & (3) & P-PE \\
\hline 1 & 0.00 & 0.00 & 0.00 & 0.00 \\
5 & 0.00 & 0.00 & 0.00 & 0.00 \\
7 & 0.20 & 0.10 & 0.18 & 0.18 \\
9 & 1.10 & 1.30 & 2.00 & 1.64 \\
\hline
\end{tabular}

(1), (2), (3), Reference to Table 1
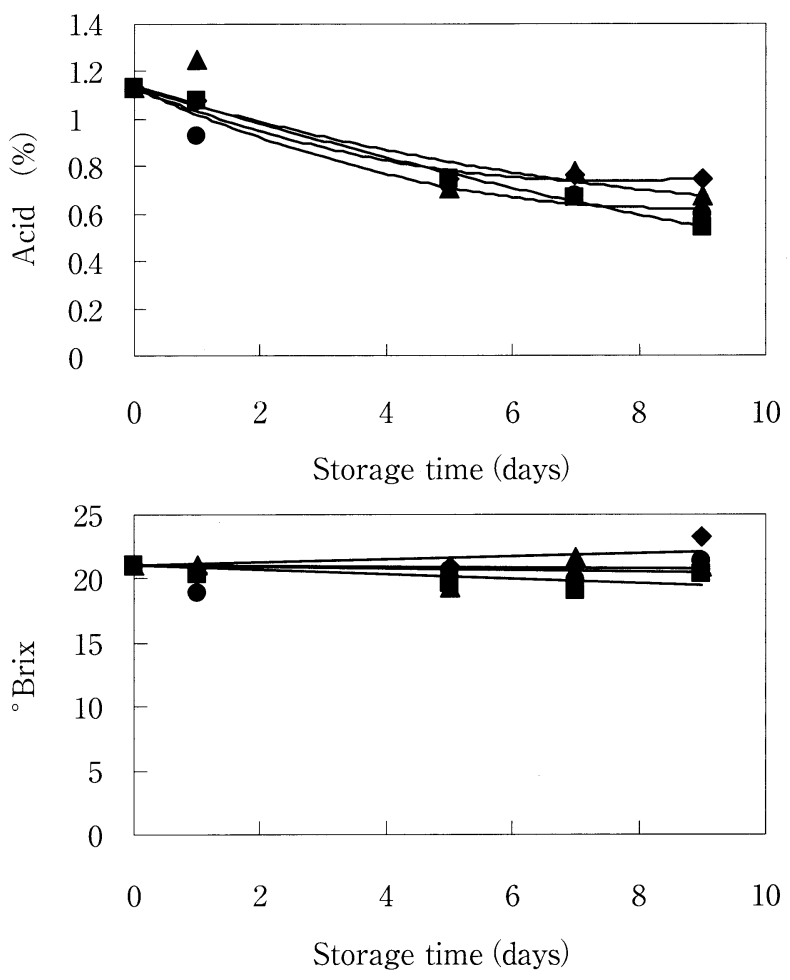

Fig. 4 Changes in acid and ${ }^{\circ}$ Brix

(1), P-PE

P-PE, Perforated low-density polyethylene, non-packaged (1), (2), (3), Reference to Table 1 


\section{5. 包装貯蔵中における糖酸度変化}

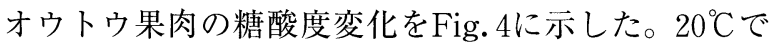
9 日間の貯蔵では, 糖度は貯蔵前と比べてほとんど変化 がみられなかった。一方，酸度は 5 日後には大きく減少 し，その後はそのままあまり変化はみられなかった。ま た，糖・酸度ともに包装条件による明確な違いは認めら れなかった。

\section{考察}

本研究では，オウトウのMA包装試験を行うにあたり, 試料の酸素消費速度と使用する包装フィルムの酸素透過 度をあらかじめ測定することにより包装条件の設定を行 った。その結果, ほぼ設計通りの包装内酸素濃度を得る ことができ，本手法の有効性を確認することができた。 ただし, 二酸化炭素濃度については, 高酸素条件では $5 \%$, 低酸素条件では $10 \%$ と設定したため, 実際にMA包装し た袋内の二酸化炭素濃度を測定してみると, 設定值と比 べてかなりずれが生じていることが明らかとなった。よ り精度の高い酸素消費速度測定を行うためには，二酸化 炭素濃度条件も十分考慮する必要があると言える。

青果物を包装した袋内のガス組成が一定である場合， フィルム面での酸素と二酸化炭素のガス透過速度が逆向 きで等しく平衡を保っているということになる。酸素と 二酸化炭素のガス透過度の比を一般に $1 ： 4$ であるとす れば，酸素と二酸化炭素の透過が平衡となるためには分 圧差が逆に 4：1になるはずである。例えば，包装内酸 素濃度が $5 \%$ であれば分圧差は約 0.16 となり, 二酸化炭 素の分圧差がその $1 / 4$ であるとすれば二酸化炭素濃度 は $4 \%$ となるはずである。このような方法で二酸化炭素 濃度を計算し，混合ガス組成を設定することにより，よ り精度の高い酸素消費速度の測定ができるものと考えて いる。

オウトウを各種ポリエチレンフィルムで包装すること により貯蔵中の目減り率が減少し, 鮮度保持が可能にな るとの報告があるが ${ }^{13)}$ ，フィルムの種類と目減り率の関 係について詳細な報告はない。本研究では, 包装フィル ムの種類により影響が, (3)<(2)<(1)の順に増加した結 果であった。包装フィルムはいずれも低密度ポリエチレ ンフィルムであるので, 袋内外の相対湿度が同じである とすれば，オウトウの目減り率の元となるフィルムの水 蒸気透過度は, 袋の厚さと面積のみに依存する。一般に, 厚さが 2 倍になれば水蒸気透過度は $1 / 2$, 面積が 2 倍 になれば水蒸気透過度は 2 倍になると考えられる。(3)

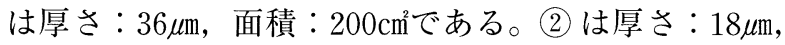
面積：200 cm゙あり，面積は (3)と同じで厚さが $1 / 2$ で あるため, 水蒸気透過度は (3) 2 倍になるはずである。 (1)は厚さ： $18 \mu \mathrm{m}$, 面積：450 $\mathrm{cm}^{2}$ であり，面積が (3)の2. 25 倍で厚さが $1 / 2$ であるため, 水蒸気透過度は (3)の 4.5 倍になるはずである。実際にTable 2 の結果を見るとほ ぼ予想通りになっていることがわかる。
オウトウのCA条件下での鮮度保持効果については, 酸素 $7 \sim 10 \%$, 二酸化炭素 $3 \sim 5 \%, 0{ }^{\circ} \mathrm{C}$ 貯蔵に打いて 目減り率や果皮の色などにおいて $2 \sim 4$ 日間の鮮度保持 効果が認められるとの報告がある ${ }^{11,14)}$ 。その他にも低酸 素, 高二酸化炭素濃度条件による鮮度保持効果は多くの 論文で報告されている ${ }^{15), 16)}$ 。一方，プラスチックフィル ムによるMA包装では包材の種類や厚さによる鮮度保持 効果の違いは認められていないものも多( ${ }^{177,18)}$ 。本研究 では, 外観評価では, 果柄の萎れで包装フィルムによる 品質保持効果が確認された。包装条件 (1)では袋内の酸 素濃度が高く, MA効果が確認されなかったが, 袋内酸 素濃度が10\%以下となった (2), (3)では明らかな品質保 持効果がみられた。このことから，オウトウの果柄萎れ に関するMA効果は少なくとも酸素濃度10\%程度以下ま で下げなければ効果が表れないものと考えられる。ただ し, 最適な酸素, 二酸化炭素濃度や鮮度保持効果は, 貯 蔵温度によっても影響を受けることが考えられる。本結 果は $20^{\circ} \mathrm{C}$ 条件下での評価であるという点に注意しておく 必要がある。

糖度はほとんど変化することなく, 酸度のみ大きく低 下した（糖酸比の低下）ことから，ややほけけた味となっ た。貯蔵中の糖酸比の低下は相橘などでも報告されてお り ${ }^{19)}$ ，オウトウでも同じように確認されたことになる。 これは, オウトウ中の酸含量が糖に比べると総量として 少ないため, 同程度の減少量であっても総量が少ない酸 含量の滅少割合が大きく見えたものと考えられる。

\section{要 約}

本研究によりオウトウの最適包装設計手法の有効性に ついて示すことができた。オウトウのMA包装試験を行 うにあたり, 試料の酸素消費速度と使用する包装フィル ムの酸素透過度をあらかじめ測定することにより包装条 件の設定を行い，その結果，ほぼ設計どおりの包装内酸 素濃度を得ることができた。この方法により，オウトウ をプラスチックフィルムで包装し，貯蔵試験を行う場合， やみくもに種々のフィルムで包装してみるというような 必要がなく, 事前に包装条件を想定しておくことが可能 となった。

オウトウをフィルム包装後, $20^{\circ} \mathrm{C}$ で貯蔵し，包装内ガ ス組成, 糖酸度などを測定した。オウトウ $100 \mathrm{~g}$ に対し て, 厚さ $18 \mu \mathrm{m}$ および $36 \mu \mathrm{m}, 10 \times 10 \mathrm{~cm}$ サイ゙のLDPE袋で 包装した場合, 包装内酸素濃度が $1 \sim 2,7 \sim 9 \%$ とな り，果柄の萎れに関する評価で良好な結果が得られた。

\section{文献}

1 ) Kader, A. A., ZAgory, D. and Kerbel, E. L. : Modified atmosphere packaging of fruits and vegetables, Critical Review. Food Sci. Nutr., 28, 1 30 (1989)

2）鈴木芳孝・岡林秀典・石川 豊 - 今堀義洋 ·上田悦 
範：新簡易包装（パーシャルシール包装）によるニラ の鮮度保持技術の開発，日食保蔵誌，29，141１46 (2003)

3 ）鈴木芳孝・今堀義洋・上田悦範：パーシャルシール 包装による葉ネギの鮮度保持技術，日食保蔵誌, 31,25 $\sim 29$ (2005)

4 ）鈴木芳孝・宮崎清宏・石川 豊・今堀義洋・上田悦 範：パーシャルシール包装によるナバナの鮮度保持技 術，日食保蔵誌，32，23～27（2006）

5 ) Tian, S., Jiang, A., Xu, Y. and Wang, Y. : Responses of physiology and quality of sweet cherry fruit to different atmospheres in storage, Food Chem., 87, 43 49 (2004)

6 ）佐藤博実・石川 豊・平田 孝：フィルム包装ブロ ッコリーの呼吸モデル，日本包装学会誌，2，25～34 (1993)

7 ) Ishikawa, Y. and Hirata, T. : Color change model for broccoli packaged in polymeric films, Trans. ASAE, 44, 923 927 (2001)

8 ) Ishikawa, Y., Hasegawa, Y., Nakajima, H. and Iba, Y. : Prediction of in-package gas composition changes in stored vegetables and fruits, Food Preser. Sci., 25, 287〜292 (1999)

9 ) Jurin, V. and Karel, M.: Studies on control of respiration of McIntosh apples by packaging methods, Food Technol., 17, 782 786 (1963)

10) Ishikawa, Y. and Hasegawa, Y.: Determination of packaging conditions for selected fresh vegetables, Food Sci. Technol. Int. Tokyo, 4, 274 277 (1998)

11）山形県立農業試験場：山形県立農業試験場業務年報 昭和48年度，95～106（1973）
12）石川豊・佐藤博実·石谷孝佑 - 平田 孝：MA (Modified Atmosphere) 包装ブロッコリーの呼吸評 価，日本包装学会誌，1，143～153（1992）

13) Hirata, T., Nishiyama, T., Sato, H., Ishikawa, Y., SHIINA, T. and Ishitani, T. : A fast gas chromatographic method for the separation of nitrogen, oxygen, carbon dioxide and argon and its application to in-packaged modified atmosphere,

J. Pack. Sci. Technol., 2, 15 24 (1993)

14）山形県立農業試験場：山形県立農業試験場業務年報 昭和49年度，95～111（1974）

15) Mattheis, J. P., Buchanan, D. A. and Fellman, J. K. : Volatile constituents of bing sweet cherry fruit following controlled atmosphere storage, $J$. Agric. Food Chem., 45, 212 216 (1997)

16) Chen, P. M., Mellenthin, W. M. , Kelly, S. B. and Facteau, T. J.: Effects of low oxygen and temperature on quality retention of 'Bing' cherries during prolonged storage, J. Amer. Soc. Hort. Sci., 106, 533 535 (1981)

17 ) Meheriuk, M., Mckenzie, D. L. , Girard, B., Moyls, A. L., Weintraub, S. , Hocking, R. and Kopp, T. : Storage of 'Sweetheart' cherries in sealed plastic film, J. Food Qual., 20, 189 198 (1997)

18）山形県立農業試験場：山形県立農業試験場業務年報 昭和47年度，99１04（1972）

19）藤澤弘幸・高原利雄・緒方達志：冷温高湿貯蔵によ り，予措をせずに貯蔵した「清見」タンゴールの果皮 障害は抑制される，園学雑，69（別 1)，213（2000） (平成 20 年 1 月 16 日受付，平成 20 年 7 月 24 日受理) 